\title{
Comparison of charantin extract from Momordica charantia using modified supercritical carbon dioxide and soxhlet extraction method
}

\author{
Ahmad Syahmi Zaini a, b, Noor Aiysah Aris a, b, Nicky Rahmana Putra a, b , Syafiza Abd Hashib d, \\ Mohd Johari Kamaruddin b, c, Zuhaili Idham a, Mohd Azizi Che Yunus a, b, \\ a Centre of Lipids Engineering \& Applied Research (CLEAR), Ibnu Sina Institute for Scientific \& Industrial Research, Universiti Teknologi Malaysia, \\ 81310 UTM Johor Bahru, Johor, Malaysia \\ ${ }^{b}$ Faculty of Chemical \& Energy Engineering, Universiti Teknologi Malaysia, 81310 UTM Johor Bahru, Johor, Malaysia \\ c Centre of Hydrogen Energy, Institute of Future Energy (IFE), Universiti Teknologi Malaysia, 81310 UTM Johor Bahru, Johor, Malaysia \\ ${ }^{d}$ Faculty of Chemical Engineering, Universiti Teknologi MARA, 40450 Shah Alam, Selangor, Malaysia \\ * Corresponding author: azizi@cheme.utm.my
}

\section{Article history}

Received 28 Mac 2018

Revised 20 May 2018

Accepted 30 November 2018

Published Online 16 December 2018

\begin{abstract}
Charantin extract from Momordica charantia fruits for the anti-diabetic compound was proposed via Supercritical Fluid Extraction using carbon dioxide $\left(\mathrm{SC}-\mathrm{CO}_{2}\right)$ as a solvent. This method is a promising alternative technique to a conventional Soxhlet and shaking water bath extraction method. Experiments were conducted to analyze the charantin i) with and without a modifier (ethanol), ii) Soxhlet extraction with four types of solvent (distilled water, ethanol, dichloromethane, and petroleum ether) and iii) shaking water bath with distilled water as a solvent. A purification step was conducted post extraction to remove intrusive components such as chlorophylls and sugar from the analyte in order to quantify charantin extract using high-performance liquid chromatography (HPLC). The results show that in 2.5 hours $\mathrm{SC}-\mathrm{CO}_{2}$ with ethanol as modifier gives highest charantin yield with $0.7817 \mathrm{mg}$ charantin per gram sample. In contrast, shaking water bath gives the highest charantin yield for a conventional method with $0.712 \mathrm{mg}$ charantin per gram sample during 6 hours of extraction. The result shows that by using $\mathrm{SC}-\mathrm{CO}_{2}$ modified with ethanol can be a promising "green" extraction than a conventional method.
\end{abstract}

Keywords: Supercritical carbon dioxide extraction, Soxhlet and shaking water bath extraction, charantin, momordica charantia, supercritical fluid extraction

(C) 2018 Penerbit UTM Press. All rights reserved

\section{INTRODUCTION}

For decades, plants have been inevitably powerful sources in providing a vast amount of compounds such as nitrogen, vitamins, phenolic, followed by metabolites that are rich in bioactivities like antioxidant, anti-carcinogenic, anti-bacterial, and anti-inflammatory (Jain and De, 2016). However, this study can be a very thoughtprovoking subject for the scientist to explore further. Hence, plants have become a major concern among researches in identifying and developing the natural colorants, biodiesel, new drugs and so forth with no or less side effect. According to Horax et al. (2010), phenolic extracts from various plants have antioxidant activities. With this intention, the demand and requirement of plant studies are increases among natural product researchers.

Bitter gourd also known as Momordica charantia in botanical name belongs to the Cucubitaceae family was selected in this research. Unripe and immature fruits are light green, firm, oblong with white flesh and are the ones harvested for consumption (Raina et al., 2016). Usually, bitter gourd is 4-6 inch long, 100-300 $\mathrm{g}$ in weight and the fruit is extremely bitter (Lucas. et al., 2010). Fig. 1 shows unripe bitter gourd used in this experiment. The main constituents of bitter gourd which are responsible for these effects like antidiabetic (Grover and Yadav, 2004; Ojewole et al., 2005), antitumorous (S. Wang et al., 2016), anticancer (Raman and Lau, 1996), anti-flamatory (Lu et al., 2012) are such as alkaloid, proteid, inorganic, lipid, tritepene, steroid and phenolic compound (Budrat and Shotipruk, 2008). As reported by Lucas. et al. (2010), bitter gourd contains protein has an ability for fighting against HIV. In addition, a steroid compound like charantin has been proven for its antidiabetic activity (Nerurkar et al., 2008).

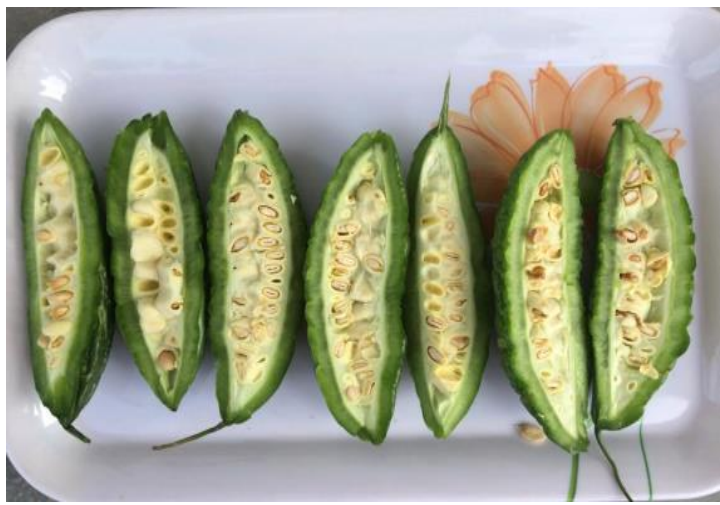

Fig. 1 Unripe Momordica charantia in January 2017 at the CLEAR laboratory.

The focus material in this research is charantin, which originally formed from a mixture of two compounds,-namely, sitosteryl glucoside 
and stigmasteryl glucoside. As mentioned by H. Y. Wang et al. (2014), charantin is one of its major bioactive compounds in bitter gourd and is believed to have an insulin-like chemical structure and properties. It consists of a steroidal portion or aglycone, which is highly soluble in a non-polar solvent such as chloroform and dichloromethane. However, the presence of glucoside that attached to its molecule makes it slightly soluble in polar organic solvent such as methanol and ethanol (Pitipanapong et al., 2007).

Recently, a favourable conventional method such as Soxhlet and shaking water bath extraction has been investigated for the extraction of several bioactive compounds from natural materials (Pitipanapong et al., 2007). Nevertheless, these conventional methods required long extraction time, dangerous handling due to exposure of toxic solvent, decreasing demand for the oils extracted with toxic organic solvents and also associated with health problems (Azmir et al., 2013; Belayneh et al., 2017). Due to long extraction time, Soxhlet extraction would require a large volume of solvent as well as loss of flavonoids due to oxidation, hydrolysis and ionisation during extraction.

As an alternative green technology for lipid extraction, $\mathrm{SC}-\mathrm{CO}_{2}$ is considered in this research. Fig. 2 shows the $\mathrm{SC}-\mathrm{CO}_{2}$ instrument at Centre of Lipids Engineering and Applied Research (CLEAR), Universiti Teknologi Malaysia (UTM). SC- $\mathrm{CO}_{2}$ extraction has many advantages such as less solvent used, shorter time (Shan et al., 2012), better selectivity and efficiency (Arsad et al., 2016; Mohd-Setapar et al., 2014). As carbon dioxide is a non-polar solvent, $\mathrm{SC}-\mathrm{CO}_{2}$ has limitations in the extraction of polar and moderately non-polar compounds. In order to overcome this limitation, polar modifier or cosolvents is introduced in the $\mathrm{SC}-\mathrm{CO}_{2}$ system to aid extraction of polar analytes (Ibrahim and Sarbatly, 2014). In this case, ethanol is used as co-solvent because of its good miscibily with $\mathrm{CO}_{2}$ and non-toxicity. This co-solvent is necessary in order to adjust the solvent power or the selectivity of $\mathrm{CO}_{2}$ for a better result in polar lipid components extraction.

Therefore, the objectives of this study are to distinguish the effect of co-solvent on extraction yield of $\mathrm{SC}-\mathrm{CO}_{2}$ and to contrast the extraction method between $\mathrm{SC}-\mathrm{CO}_{2}$ and conventional extraction.

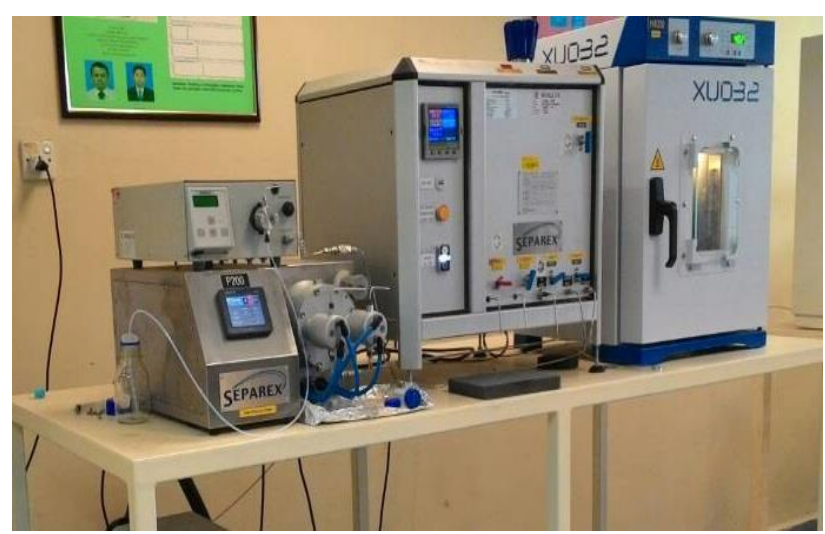

Fig. 2 Supercritical Carbon Dioxide $\left(\mathrm{SC}-\mathrm{CO}_{2}\right)$ Instrument in September 2017 at CLEAR laboratory.

\section{EXPERIMENTAL}

\section{Moisture content determination}

In $\mathrm{SC}-\mathrm{CO}_{2}$ of the natural product, fresh plant material are required if the desired bioactive compound is volatile or labile. High moisture content in a fresh sample can cause mechanical difficulties such as restrictor clogging due to ice formation (Lang and Wai, 2001). Therefore, moisture content in a fresh sample of Momordica charantia (bitter gourd) needs to be controlled.

Unripe bitter gourd was purchased from a local market. 10 grams of small pieces bitter gourd sample was weighed and placed in the crucible and dried in the oven at $135 \pm 2{ }^{\circ} \mathrm{C}$ for three hours. The crucible then was closed with its lid and immediately placed in desiccators for a cooling process. The crucible was weighed until constant weight was achieved. The wet basis moisture content is calculated as a percentage by mass of the samples using Eq. (1)
Moisture Content $(\%)=\frac{\left(m_{1}-m_{2}\right)}{\left(m_{1}-m_{0}\right)} \times 100$

Where $\quad m_{0}=$ mass of crucible $(\mathrm{g})$

$\mathrm{m}_{1}=$ mass of crucible with sample before drying $(\mathrm{g})$

$\mathrm{m}_{2}=$ mass of crucible with sample after drying $(\mathrm{g})$

From equation 1, moisture content in bitter gourd obtained was $93.03 \%$. Due to high moisture content, this sample needs to undergo drying phase before it can be extracted using $\mathrm{SC}-\mathrm{CO}_{2}$. Therefore, the whole sample was oven-dried at temperature $50{ }^{\circ} \mathrm{C}$ and 24 hours until it reduces moisture content less than $10 \%$.

\section{Sample preparation and chemicals}

The fruits were cut into small pieces after rinsed with distilled water and then oven dried at $50{ }^{\circ} \mathrm{C}$ for 24 hours before grinding. The dried bitter gourd was completely crushed using a commercial blender (Philips). The ground sample was sieved (Retshch, Germany) and particle sizes chosen was $\pm 300 \mu \mathrm{m}$. The grounded sample was stored and keep in the freezer $\left(-20^{\circ} \mathrm{C}\right)$ (Model Liebherr) until used.

Chemicals used were ethanol, dichloromethane and petroleum ether that purchased from Merck, Malaysia and the charantin standard were purchased from ChromaDex.

\section{Supercritical carbon dioxide $\left(\mathrm{SC}-\mathrm{CO}_{2}\right)$ extraction}

A SC- $\mathrm{CO}_{2}$ unit was designed as shown in Figure 3, which consists of force ventillation oven fitted with a $50 \mathrm{~mL}$ stainless steel extraction vessel (MMM Group, German) and the pressure in the vessel was regulated by means of a back-pressure (Tescom Corp., US) valve installed in the line between the extraction vessel and the separator. Water circulation bath (Daihan Scientific. Co. Ltd, Korea) helps to depressurize using the valve that converted the supercritical state of $\mathrm{CO}_{2}$ into a gaseous state which then separated $\mathrm{CO}_{2}$ from the extracted oil. A constant flow rate carbon dioxide gas (Mega Mount Industrial Gases Sdn Bhd, Malaysia) at $4 \mathrm{~mL} / \mathrm{min}$ and $99.99 \%$ purity was liquidized using a refrigerated bath circulator (Daihan Scientific. Co Ltd, Korea) and pumped to an extractor using carbon dioxide liquid pump (Tokyo, Japan).

The supercritical extraction was performed with and without cosolvent, ethanol using $5 \mathrm{~g}$ of the ground bitter gourd at $20 \mathrm{MPa}$ and 65 ${ }^{\circ} \mathrm{C}$ for 150 minutes with 25 minutes interval to collect the extract yield. The samples were loaded into the extraction cell and tightly sealed and then placed in the extraction chamber to let the system reach the desired condition. The extraction has begun after the system had reached the desired condition. $\mathrm{CO}_{2}$ gas was depressurized in order to remove from the separator. The amount of extract oil yield obtained from $\mathrm{SC}-\mathrm{CO}_{2}$ was calculated using Eq. 2 and then it is stored in a freezer $\left(-20^{\circ} \mathrm{C}\right)$ for charantin analysis.

Percentage yield $(\%)=\frac{\text { Extract yield }(g)}{\text { Initial sample }(g)} \times 100$

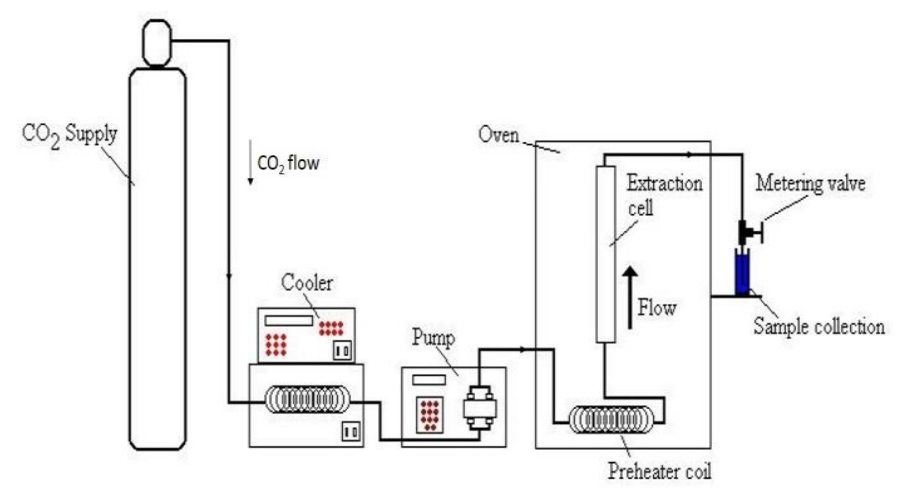

Fig. 3 Schematic diagram for supercritical carbon dioxide extraction.

\section{Water extraction}

Water extraction was performed using shaking water bath instrument (NE5-28D Series Clifton, Nickel-Electro Limited, United 
Kingdom, UK) at Centre of Lipids Engineering and Applied Research (CLEAR). The extraction was conducted at $80{ }^{\circ} \mathrm{C}$ with 6 hours extraction time. Water extract then evaporated using an oven at $60^{\circ} \mathrm{C}$ and the remaining oil left was kept and stored in a freezer $\left(-20^{\circ} \mathrm{C}\right)$ for charantin analysis.

\section{Soxhlet extraction}

Soxhlet extraction was carried out using a Soxhlet apparatus. A 20 $\mathrm{g}$ of grounded bitter gourd was added into 4 round bottom flask with $200 \mathrm{~mL}$ of different solvent each. The Soxhlet extraction takes about 6 hours to complete. The solvent used was distilled water, ethanol, dichloromethane, and petroleum ether (Merck, Malaysia) with boiling point $100^{\circ} \mathrm{C}, 78.37^{\circ} \mathrm{C}, 39.6^{\circ} \mathrm{C}$ and $42-62^{\circ} \mathrm{C}$ at 1 atm respectively. The next step is, solvents were removed via rotary evaporator (Heidolph, German) at a temperature slightly above the boiling point of the solvent and remaining oil yield then were stored in the freezer $\left(-20^{\circ} \mathrm{C}\right)$ for charantin analysis.

\section{Sample purification}

Extract oil was purified according to the previous study with some modification (Pitipanapong et al., 2007). Concisely, $2 \mathrm{~mL}$ of methanolwater with ratio $1: 1$ was added to $0.2 \mathrm{~g}$ of extract oil. The mixture was sonicated for 15 minutes and centrifuged at $3500 \mathrm{rpm}$ for another 15 min to separate the supernatant from the precipitate. The precipitate was added with $1 \mathrm{~mL}$ of methanol and repeated with sonication and centrifuge steps. The purified solution was filtered through a $0.45 \mu \mathrm{m}$ nylon membrane filter (Millipore, US) before analyzed using HighPerformance Liquid Chromatography (HPLC). HPLC analysis was performed as the previous study as well by Pitipanapong et al. (2007) with C-18 Inertsil ODS-3 column (5 $\mu \mathrm{m}$ particle, $4.6 \mathrm{~mm}$ x $250 \mathrm{~mm}$ ID). The mobile phase was 100:2 (v/v) methanol-water and was delivered at a flow rate of $1 \mathrm{~mL} / \mathrm{min}$. The UV detection wavelength was $204 \mathrm{~nm}$ and the sample injection volume was $200 \mu \mathrm{L}$.

\section{RESULTS AND DISCUSSION}

\section{Effect of co-solvent on the $\mathrm{SC}-\mathrm{CO}_{2}$ extraction yield}

Figure 4 presents the percentage yield of $\mathrm{SC}-\mathrm{CO}_{2}$ at $20 \mathrm{MPa}$ and $65^{\circ} \mathrm{C}$ with and without ethanol as co-solvent. It can be seen that the extraction of charantin with co-solvent ethanol gives the highest percentage yield with $1.924 \%$ compared to the absence of ethanol, $1.294 \%$. This phenomenon can be explained in terms of diffusivity and target compound extracted. The addition of ethanol as co-solvent was found to be favourable for the extraction in $\mathrm{SC}-\mathrm{CO}_{2}$ at $20 \mathrm{MPa}$ and 65 ${ }^{\circ} \mathrm{C}$. According to Machmudah et al. (2006), the ethanol addition will enhance the solvent power in $\mathrm{SC}-\mathrm{CO}_{2}$ and caused swelling of the matrix, thus increasing the internal volume and the surface area for the contact with $\mathrm{SC}-\mathrm{CO}_{2}$. The addition of ethanol in $\mathrm{SC}-\mathrm{CO}_{2}$ can penetrate into the porous solid materials more efficiently. Therefore, it may render much faster mass transfer resulting in a more rapid and efficient extraction (M. A. C. Yunus et al., 2007).

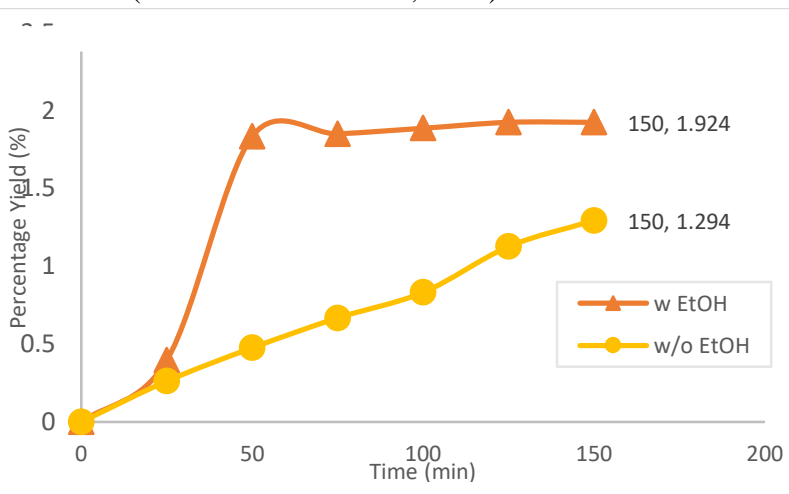

Fig. 4 Percentage oil yield at $20 \mathrm{MPa} \& 65^{\circ} \mathrm{C}$ with ethanol and without ethanol.

Additionally, the polarity of the target compound may affect the extraction yield as it depends on the polarity of the solvent. Extraction using pure $\mathrm{SC}-\mathrm{CO}_{2}$ (without ethanol) gives the lowest percentage yield compared to extraction with ethanol as co-solvent. As pure carbon dioxide is non-polar solvent and the presence of ethanol increase the polarity of the solvent, this obvious gap explains that most of the target compound in bitter gourd were polar compound. Since the polar lipid dissolves and soluble in the polar solvent, it can be said that extract yield of bitter gourd is a polar lipid. Same results trend were reported by Machmudah et al. (2006) where the presence of $1.67 \%$ ethanol using $\mathrm{SC}-\mathrm{CO}_{2}$ extraction was found to enhanced the amount of astaxanthin extract from 10 to $20.5 \%$ at higher pressure (40MPa) while at low pressure (20MPa) the extract was from 0.6 to $6.6 \%$.

\section{Comparison of extraction yield between $\mathrm{SC}-\mathrm{CO}_{2}$ and conventional method}

The extraction of bitter gourd oil in this research was done by using three extraction methods namely $\mathrm{SC}-\mathrm{CO}_{2}$, shaking water bath and Soxhlet extraction. The results obtained for the extract oil yield were compared between these three methods.

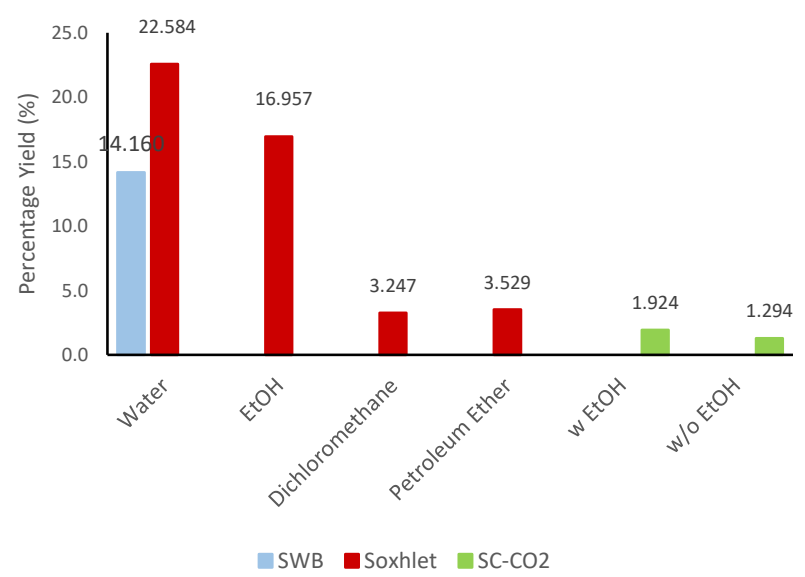

Fig. 5 Percentage yield of Momordica charantia in shaking water bath extraction, Soxhlet extraction with a different solvent (ethanol, dichloromethane, petroleum ether) and $\mathrm{SC}-\mathrm{CO}_{2}$ extraction (with and without ethanol).

Figure 5 shows percentage yield of bitter gourd in shaking water bath extraction; water as solvent, Soxhlet extraction with solvent water (b.p $100{ }^{\circ} \mathrm{C}$ ), ethanol (b.p $78.3^{\circ} \mathrm{C}$ ), dichloromethane (b.p $39.6{ }^{\circ} \mathrm{C}$ ) and petroleum ether (b.p $60-80^{\circ} \mathrm{C}$ ) and $\mathrm{SC}-\mathrm{CO}_{2}$ extraction with pure carbon dioxide and addition of co-solvent ethanol.

Based on Figure 5, it can obviously be seen that using water as a solvent in shaking water bath and Soxhlet extraction gives the highest percentage yield among others solvent and $\mathrm{SC}-\mathrm{CO}_{2}$ method with $14.16 \%$ and $22.58 \%$ respectively. It clearly shows that most compounds in bitter gourd were a slightly polar molecule. According to Arsad et al. (2016), Soxhlet extraction traditionally used in determining the total oil and also capable to extract a group of resin and waxes, so the oil yield of Soxhlet extraction may be more than other methods. This trend also applies to shake water bath extraction. On the other hands, Soxhlet with ethanol, dichloromethane and petroleum ether solvents give $16.96 \%$, $3.25 \%$ and $3.53 \%$ respectively meanwhile $\mathrm{SC}-\mathrm{CO}_{2}$ with and without the addition of ethanol gives $3.70 \%$ and $1.29 \%$ respectively. From the result obtained between Soxhlet and $\mathrm{SC}-\mathrm{CO}_{2}$ extraction, it shows a comparison of percentage yield between the polar solvent (water and ethanol in Soxhlet; $\mathrm{SC}-\mathrm{CO}_{2}$ with ethanol) and non-polar solvent (dichloromethane and petroleum ether in Soxhlet; pure $\mathrm{SC}-\mathrm{CO}_{2}$ ) where both polar and non-polar solvent in the Soxhlet method resulted in higher percentage of extract yield compared to $\mathrm{SC}-\mathrm{CO}_{2}$ extraction. The same result's trend was recorded in the previous research by $\mathrm{M}$. Yunus (2007) where $\mathrm{SC}-\mathrm{CO}_{2}$ gives lower extracted oil yield than Soxhlet in Pitchecellobium Jiringan (Jack) prain seeds extraction. In addition, Soxhlet extraction was capable to extract the groups of oleoresin and waxy materials in the outer part of the ground raw materials (Arsad $e t$ al., 2016; Lee et al., 2013). 
On the other hand, Soxhlet extraction with water as a solvent also comparable to shaking water bath extraction as shaking water bath extraction involves most of the Soxhlet disadvantages but none of its advantages. Although both of these methods used a high volume of solvent, Soxhlet extraction gives high extraction efficiency compared to shaking water bath as it does not require filteration after the extraction step. Even though the extraction using a shaking water bath with some modification to improve the overall efficiency, it hardly surpasses that Soxhlet extraction (De Castro and Garcia-Ayuso, 1998).

\section{Comparison of Charantin Yield between $\mathrm{SC}^{-\mathrm{CO}_{2}}$ and Conventional Method}

Figure 6 shows the comparison of charantin contains in bitter gourd extract from $\mathrm{SC}-\mathrm{CO}_{2}$ and conventional (shaking water bath and Soxhlet) method. It is clearly shown that charantin obtained from SC$\mathrm{CO}_{2}$ with ethanol is the highest compared to the other two conventional methods. In addition, dichloromethane gives higher charantin contain in Soxhlet extraction compared to the other solvent.

Based on this comparison, it shows that the $\mathrm{SC}-\mathrm{CO}_{2}$ extraction is better than the conventional method in order to obtain the higher value of charantin contain in extract yield. Even though $\mathrm{SC}-\mathrm{CO}_{2}$ gives lower extract yield compared to the conventional one, it is proven that SC$\mathrm{CO}_{2}$ is high selectivity as the extract yield contain rich charantin. According to M. C. Yunus et al. (2013), SC- $\mathrm{CO}_{2}$, have the ability to modify their selectivity by modifying the fluid density (varying the temperature and pressure).

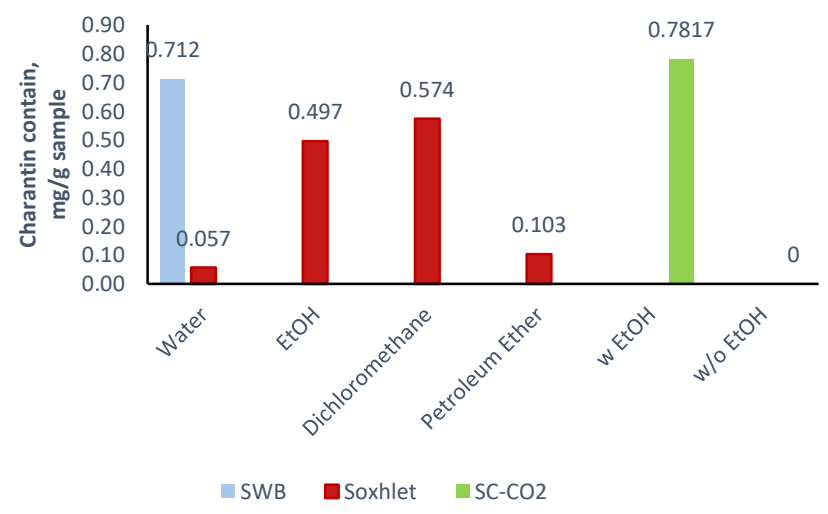

Fig. 6 Amount of charantin contain in Momordica charantia extract in shaking water bath, Soxhlet extraction with a different solvent (ethanol, dichloromethane, petroleum ether) and $\mathrm{SC}-\mathrm{CO}_{2}$ extraction (with and without ethanol).

Although charantin contain in shaking water bath extraction gives slightly lower than extraction using $\mathrm{SC}-\mathrm{CO}_{2}$ with ethanol, it is not practical as the extraction using shaking water bath consumes a longer extraction time which is in this case 6 hours compared to $\mathrm{SC}-\mathrm{CO}_{2}, 150$ minutes. In addition, consuming long extraction time required a lot of energy during the extraction process, thus the process is not green to the environment.

\section{CONCLUSION}

Generally, there have many methods to extract charantin from Momordica charantia (bitter gourd). In this research, the $\mathrm{SC}-\mathrm{CO}_{2}$ which is known as green technology extraction was used to extract charantin from bitter gourd. Moreover, a conventional method such as shaking water bath and Soxhlet extraction were also used in this experiment. Comparison of extraction and charantin yield were investigated in this research. The highest extraction yield $(22.584 \%)$ is obtained by using Soxhlet extraction with water as solvent meanwhile lowest yield (1.294\%) is obtained by using pure $\mathrm{SC}-\mathrm{CO}_{2}$. Despite the extraction yield obtained from $\mathrm{SC}-\mathrm{CO}_{2}$ was lower than Soxhlet and shaking water bath extraction, with the presence of modifier ethanol, the $\mathrm{SC}-\mathrm{CO}_{2}$ extraction method was more selective compared to conventional extraction as the charantin contain using $\mathrm{SC}-\mathrm{CO}_{2}$ method with modifier ethanol $(0.7817 \mathrm{mg}$ charantin/g sample) was higher than that obtained by conventional extraction method. Therefore, $\mathrm{SC}-\mathrm{CO}_{2}$ modified with ethanol can be a promising "green" extraction method than the conventional extraction method.

\section{ACKNOWLEDGEMENT}

The authors would like to thank the Department of Chemical and Energy Engineering of the "Universiti Teknologi Malaysia" as well as Ministry of Higher Education, MOHE for the special support that made this research possible and also the financial support from Universiti Teknologi Malaysia under COE grant (Q.J130000.2446.04G03) and GUP grant (Q.J130000.2509.16H87).

\section{REFERENCES}

Arsad, N. H., Yunus, M. A. C., Zaini, M. A. A., Rahman, Z. A. and Idham, Z. (2016). Effect of operating conditions of supercritical carbon dioxide on piper betle leave oil yield and antioxidant activity. International Journal of Applied Chemistry, 12(4), 741-751.

Azmir, J., Zaidul, I. S. M., Rahman, M. M., Sharif, K. M., Mohamed, A., Sahena, F., . . . Omar, A. K. M. (2013). Techniques for extraction of bioactive compounds from plant materials: A review. Journal of Food Engineering, 117(4), 426-436.

Belayneh, H. D., Wehling, R. L., Reddy, A. K., Cahoon, E. B. and Ciftci, O. N. (2017). Ethanol-modified supercritical carbon dioxide extraction of the bioactive lipid components of Camelina sativa seed. Journal of the American Oil Chemists' Society, 94(6), 855-865.

Budrat, P. and Shotipruk, A. (2008). Extraction of phenolic compounds from fruits of bitter melon (Momordica charantia) with subcritical water extraction and antioxidant activities of these extracts. Chiang Mai Journal of Science, 35(1), 123-130.

De Castro, M. L. and Garcia-Ayuso, L. (1998). Soxhlet extraction of solid materials: an outdated technique with a promising innovative future. Analytica Chimica Acta, 369(1), 1-10.

Grover, J. K. and Yadav, S. P. (2004). Pharmacological actions and potential uses of Momordica charantia: a review. Journal of Ethnopharmacology, 93(1), 123-132. doi: 10.1016/j.jep.2004.03.035

Horax, R., Hettiarachchy, N. and Chen, P. Y. (2010). Extraction, quantification, and antioxidant activities of phenolics from pericarp and seeds of bitter melons (Momordica charantia) harvested at three maturity stages (immature, mature, and ripe). Journal of Agricultural and Food Chemistry, 58(7), 4428-4433.

Ibrahim, A. and Sarbatly, R. (2014). Effects of Modifier polarity on extraction of limonene from citrus sinensis L. Osbeck Using supercritical carbon dioxide. Malaysian Journal of Fundamental and Applied Sciences, $8(2), 115-120$.

Jain, A. and De, S. (2016). Aqueous extraction of bitter gourd (Momordica charantia L.) juice and optimization of operating conditions. Fruits, 71(6), 379-387.

Lang, Q. and Wai, C. M. (2001). Supercritical fluid extraction in herbal and natural product studies - a practical review. Talanta, 53(4), 771-782.

Lee, N. Y., Setapar, S. H. M., Sharif, N. S. M., Ahmad, A., Khatoon, A., Yunus, M. A. C., and Muhamad, I. I. (2013). Extraction of rubber (Hevea brasiliensis) seed oil using supercritical carbon dioxide and soxhlet extraction. Research Journal of Chemistry and Environment, 17, 1-7.

Lu, Y.-L., Liu, Y.-H., Chyuan, J.-H., Cheng, K.-T., Liang, W.-L. and Hou, W.C. (2012). Antioxidant activities of different wild bitter gourd (Momordica charantia L. var. abbreviata Seringe) cultivars. Botanical Studies, 53(2), 207-214.

Lucas., E. A., Dumancas., G. G., Smith, B. J. and Clarke, S. L. (2010). Health Benefits of Bitter Melon (Momordica Charantia). Bioactive Foods in Promoting Health: Fruits and Vegetables.San Diego: Academic Press.

Machmudah, S., Shotipruk, A., Goto, M., Sasaki, M., and Hirose, T. (2006). Extraction of astaxanthin from Haematococcus p luvialis using supercritical $\mathrm{CO} 2$ and ethanol as entrainer. Industrial \& Engineering Chemistry Research, 45(10), 3652-3657.

Mohd-Setapar, S., Nian-Yian, L., and Mohd-Sharif, N. (2014). Extraction of rubber (hevea brasiliensis) seed oil using soxhlet method. Malaysian Journal of Fundamental and Applied Sciences, 10(1).

Nerurkar, P. V., Lee, Y. K., Motosue, M., Adeli, K., and Nerurkar, V. R. (2008). Momordica charantia (bitter melon) reduces plasma apolipoprotein B-100 and increases hepatic insulin receptor substrate and phosphoinositide-3 kinase interactions. Br J Nutr, 100(4), 751-759.

Ojewole, J., Adewole, S. O., and Olayiwola, G. (2005). Hypoglycaemic and hypotensive effects of Momordica charantia Linn (Cucurbitaceae) whole- 
plant aqueous extract in rats. Cardiovascular journal of South Africa: official journal for Southern Africa Cardiac Society [and] South African Society of Cardiac Practitioners, 17(5), 227-232.

Pitipanapong, J., Chitprasert, S., Goto, M., Jiratchariyakul, W., Sasaki, M., and Shotipruk, A. (2007). New approach for extraction of charantin from Momordica charantia with pressurized liquid extraction. Separation and Purification Technology, 52(3), 416-422. Raina, K., Kumar, D., and Agarwal, R. (2016). Promise of bitter melon (Momordica charantia) bioactives in cancer prevention and therapy. Semin Cancer Biol, 40-41, 116-129.

Raman, A., and Lau, C. (1996). Anti-diabetic properties and phytochemistry of Momordica charantia L. (Cucurbitaceae). Phytomedicine, 2(4), 349-362.

Shan, B., Xie, J.-H., Zhu, J.-H., and Peng, Y. (2012). Ethanol modified supercritical carbon dioxide extraction of flavonoids from Momordica charantia L. and its antioxidant activity. Food and Bioproducts Processing, 90(3), 579-587.

Wang, H. Y., Kan, W. C., Cheng, T. J., Yu, S. H., Chang, L. H., and Chuu, J. J. (2014). Differential anti-diabetic effects and mechanism of action of charantin-rich extract of Taiwanese Momordica charantia between type 1 and type 2 diabetic mice. Food Chem Toxicol, 69, 347-356.

Wang, S., Zheng, Y., Xiang, F., Li, S., and Yang, G. (2016). Antifungal activity of Momordica charantia seed extracts toward the pathogenic fungus Fusarium solani L. Journal of Food and Drug Analysis, 24(4), 881-887.

Yunus, M. (2007). Extraction, Identification, and Separation of Vitamin E and Djenkolic Acid from Pithecellobium jiringan (Jack) Prain Seeds using Supercritical Carbon Dioxide. Doctor Philosophy, Universiti Sains Malaysia, Penang.

Yunus, M. A. C., Bahari, W., Setianto, and Manan, Z. (2007) Application of supercritical fluid in the extraction of active compounds from plant material. Advances in Separation Processes, 31-62.

Yunus, M. C., Arsad, N., Zhari, S., Idham, Z., Setapar, S., and Mustapha, A. (2013). Effect of supercritical carbon dioxide condition on oil yield and solubility of Pithecellobium Jiringan (Jack) Prain seeds. $J$. Teknologi, 60, 45-50. 